\title{
Bacterial Contamination of Mobile Phones of Health Care Providers in a Teaching Hospital in Hamadan Province, Iran
}

\author{
Iraj Sedighi ${ }^{1}$; Mohammad Yousef Alikhani ${ }^{2,}$; Samira Ramezani ${ }^{3}$; Mansour Nazari ${ }^{4}$; Amir \\ Sasan Mozaffari Nejad ${ }^{5}$ \\ ${ }^{1}$ Department of Pediatrics, Faculty of Medicine, Hamadan University of Medical Sciences, Hamadan, IR Iran \\ ${ }_{2}^{2}$ Brucellosis Research Center, Hamadan University of Medical Sciences, Hamadan, IR Iran \\ ${ }^{3}$ Department of Pediatrics, Hamadan University of Medical Sciences, Hamadan, IR Iran \\ ${ }_{5}^{4}$ Department of Medical Parasitology, School of Medicine, Hamadan University of Medical Sciences, Hamadan, IR Iran \\ 5 Repartment of Medical Parasitology, School of Medicine, Hamadan University of Medical Sciences, \\ ${ }^{*}$ Corresponding author: Mohammad Yousef Alikhani, Brucellosis Research Center, Hamadan University of Medical Sciences, Hamadan, IR Iran. Tel: +98-8118380755, Fax: +98- \\ 8118380130, E-mail: alikhani43@yahoo.com; alikhani@umsha.ac.ir
}

Received: July 16, 2014; Revised: February 20, 2015; Accepted: February 22, 2015

\begin{abstract}
Background: The use of mobile phone by clinical staffs enhances transmission of pathogens and therefore, might intensify the hardship of interrupting infection spread.

Objectives: The aim of this study was to determine bacterial colonization on the mobile phones used by clinical staffs in hospitals.

Patients and Methods: We randomly selected and examined 250 mobile phones from their users. The phones were obtained from the following study groups: Group A, 125 clinical staffs including physicians, nurses, residents, and interns; and group B, 125 university headquarters staffs. Isolated microorganisms were identified using biochemical tests such as Gram stain, morphology, catalase, and oxidase reaction, and all isolates were allocated to appropriate genera. Antibiotic sensitivity test was done using the Kirby-Bauer disc diffusion method.

Results: In total, $99.2 \%$ of mobile phones in clinical staffs group demonstrated growth of bacterial species. The most common isolate were consecutively coagulase-negative staphylococci (82.4\%), Staphylococcus aureus (20.0\%), and Pseudomonas aeruginosa (12.0\%). Among controls, 93.6\% of mobile phones demonstrated growth of bacterial species. For eradication of coagulase-negative staphylococci, the highest resistance rate was detected to oxacillin. For inhibition of S. aureus, the highest resistance was detected to Oxacillin. For eradicating P. aeruginosa, considerable resistance rate to ampicillin was detected in both study groups.

Conclusions: Mobiles contamination with different pathogens is extremely common among our health care staffs compared with other societies, and resistance of these isolates to various antibiotics is also detectable. Thus, quick assessment of this issue to prevent the spread of these infectious agents is critical for the authorities in our health care systems.
\end{abstract}

Keywords: Mobile Phone; Bacterial Infection; Healthcare; Iran

\section{Background}

Nowadays, mobile phone is being widely used as one of the indispensable accessories and its usage has increased dramatically worldwide. Despite the potential benefits of mobile in facilitating communications, this device has been considered as one of the most important factors that threatens human health, e.g. transmitting microbial germs from one person to another $(1,2)$. This is especially important in health centers because the constant handling of the mobile phones by hospital staffs facilitates gathering various types of nosocomial germs that can become an important source for transmission of these infections (3). In fact, the use of mobile phone by clinical staffs can enhance pathogen transmission and might intensify the hardship of interrupting infection spread (4). Furthermore, colonization of potentially pathogenic organisms on phones may lead to the rise of antibiotic resistance. Nosocomial infections and their transmission are important health prob- lems in almost all hospitals (5). Despite the highest hygiene standards in hospital wards, bacterial transmission to the patients by the contaminated hands of health care workers commonly occurs (6). On the other hand, therapeutic settings are now considered as favorable environment for the spread of infections transmitted though hand contact (7). In Iran, there has been a considerable increase in the use of mobile phones among the general population, and the use of this communication tool, especially in unnecessary times, is common in certain areas where the rate of bacteria presence is likely high, i.e. hospitals. According to recent reports, in terms of mobile provision, Iran now surpassed most of the countries in the world and over 45 million Iranians have access to personal mobile phones (8). According to these reports, high contamination with nosocomial infections in the hospitals through the frequent use of mobile phones in our country is expectable.

Copyright (C) 2015, Infectious Diseases and Tropical Medicine Research Center. This is an open-access article distributed under the terms of the Creative Commons Attribution-NonCommercial 4.0 International License (http://creativecommons.org/licenses/by-nc/4.0/) which permits copy and redistribute the material just in noncommercial usages, provided the original work is properly cited. 


\section{Objectives}

The present study was conducted to determine bacterial colonization on the mobile phones used by clinical staffs in hospitals and compared it with other headquarters staffs. Moreover, we assessed the antibacterial resistance patterns of different isolates from these phones in a referral hospital in Hamadan, Iran.

\section{Patients and Methods}

This cross-sectional study was conducted at the Besat Hospital in Hamadan province, Iran, from 2010 to 2011. The Besat Hospital is a governmental, referral, and specialized hospital with 26 section included 540 bed. A total of 250 mobile phones were randomly selected and examined. The phones were obtained from the following study groups: Group A, 125 clinical staffs including physicians, nurses, residents, and interns; and group B, 125 university headquarters staffs as the control. The following exclusion criteria were applied: the staffs who were receiving immunosuppressive drugs or antibiotics within the preceding two weeks. In addition, the history of hospitalization during the preceding month in staffs or one of their family members was another exclusion criterion. Before commencing the study, the proposal of this project was approved by the ethical review committee of Hamadan University of Medical Sciences (code, 89051277600; date, 15/05/2010). Study participants were informed of the study and only volunteers were participated in the study. The informed consent was obtained from enrolled individuals. During the study period, 145 health professionals had direct contact with patients. From these individuals 125 volunteered to participate and were included in this study. For sampling the staff's' mobile phone, sterile moistened swab (dipped in sterile saline) was fully stretched on the mobile phone keyboard and was inoculated in the TSB medium (Merck, Germany) for transport, immediately sealed, and transferred to the microbiology laboratory at the Medicine Faculty. All samples were collected by one person. The TSB media were incubated at $37^{\circ} \mathrm{C}$ for 12 hours aerobically, then they were inoculated onto blood agar and MacConkey agar plates and incubated at $37^{\circ} \mathrm{C}$ for 24 to 48 hours. Isolated micro- organisms were identified using biochemical standard methods such as gram stain, morphology, catalase, and oxidase reaction, and all isolates were allocated to the appropriate genera. Antibiotic sensitivity test was done using the Kirby-Bauer disc diffusion method on MuellerHinton agar according to the guidelines of Clinical Laboratory Standards Institute (9). Data were entered and analyzed using SPSS 16 (SPSS Inc. Chicago, Illinois, the United States), summarized in frequencies and percentages, and presented in tables. Chi square test was used to assess the association between groups and P value $<0.05$ was considered as statistically significant.

\section{Results}

Among 125 clinical staffs, 15 (12.0\%) were physicians, 10 (8.0\%) were residents, 31 (24.8\%) were interns, and 69(55.2\%) were nurses. Table 1 shows the number of mobile phones from which we isolated bacterial organisms in the target and control population. In total, $99.2 \%$ of mobile phones in clinical staff group demonstrated growth of bacterial species. The most common isolated bacteria were consecutively coagulase-negative staphylococci (82.4\%), Staphylococcus aureus (20.0\%), and Pseudomonas species (12.0\%). Among controls, $93.6 \%$ of mobile phones demonstrated growth of bacterial species; the most common isolated bacteria were coagulase-negative staphylococci (77.6\%). As presented in Table 1, most of the isolates were more prevalent in the case group than the control group, but isolated Pseudomonas species in phones of clinical staffs were more frequent in the latter. Regarding type of grown bacteria, in target group, 76.0\% grew one bacterial species and 23.2\% grew two species, while these rates in the control group were $84.8 \%$ and $8.8 \%$, respectively. Antimicrobial susceptibility tests for the isolates in both groups (Table 2 ) revealed that for eradication of coagulase-negative staphylococci, the highest resistance rate was detected for oxacillin that was higher in the case than in the control group. In addition, for inhibition of S. aureus, the highest resistance was detected for oxacillin that was slightly lower in the former group. However, for eradication of Pseudomonas species, considerable resistance rate to ampicillin was detected in both study groups.

\begin{tabular}{lccc}
\hline \multicolumn{1}{l}{ Table 1. Common Isolated Microorganisms in the Case and Control Groups ${ }^{\text {a }}$} & & \\
\hline Isolates & Case Group $(\mathbf{n}=\mathbf{1 2 5})$ & Control Group (n=125) & P Value \\
\hline Coagulase-negative Staphylococci & $103(82.4)$ & $97(77.6)$ & 0.791 \\
Staphylococcus aureus & $25(20.0)$ & $20(16.0)$ & 0.493 \\
Pseudomonas species & $15(12.0)$ & $3(2.4)$ & 0.006 \\
Salmonella paratyphi & $10(8.0)$ & $3(2.4)$ & 0.053 \\
Corynebacterium species & $4(3.2)$ & $1(0.8)$ & 0.370 \\
Acinetobacter species & $1(0.8)$ & $0(0.0)$ & 0.999 \\
Bacillus species & $1(0.8)$ & $0(0.0)$ & 0.999 \\
Escherichia coli & $0(0.0)$ & $3(2.4)$ & 0.247 \\
\hline
\end{tabular}

\footnotetext{
${ }^{\mathrm{a}}$ Data are presented as No. (\%).
} 
Table 2. Resistance to Antibiotics in the Detected Microorganisms in Case and Control Groups a

\begin{tabular}{lcc}
\hline Isolates & $\begin{array}{c}\text { Case Group } \\
(\mathbf{n}=\mathbf{1 2 5})\end{array}$ & $\begin{array}{c}\text { Control Group } \\
(\mathbf{n}=\mathbf{1 2 5})\end{array}$ \\
\hline $\begin{array}{l}\text { Coagulase-negative Staphy- } \\
\text { lococci }\end{array}$ & & \\
\hline Ampicillin & $25(20.0)$ & $24(19.2)$ \\
\hline Oxacillin & $75(60.0)$ & $50(40.0)$ \\
\hline Cephalothin & $10(8.0)$ & $4(3.2)$ \\
\hline Clindamycin & $27(21.6)$ & $15(12.0)$ \\
\hline Vancomycin & $0(0.0)$ & $0(0.0)$ \\
\hline Staphylococcus aureus & & \\
\hline Ampicillin & $0(0.0)$ & 10.0 \\
\hline Oxacillin & $35(28.0)$ & $43(34.4)$ \\
\hline Cephalothin & $0(0.0)$ & $0(0.0)$ \\
\hline Clindamycin & $0(0.0)$ & $0(0.0)$ \\
\hline Vancomycin & $0(0.0)$ & $0(0.0)$ \\
\hline Pseudomonas & & \\
\hline Ampicillin & $125(100)$ & $125(100)$ \\
\hline Ceftazidime & $16(12.8)$ & $41(32.8)$ \\
\hline Amikacin & $0(0.0)$ & $0(0.0)$ \\
\hline Gentamicin & $0(0.0)$ & $0(0.0)$ \\
\hline a Data are presented as No.(\%). & & \\
\hline
\end{tabular}

\section{Discussion}

The current study showed a high prevalence of bacterial colonization in mobiles of both clinical and university headquarters' staffs with higher prevalence in the former group. Among different isolates, coagulase-negative staphylococci species were the commonest pathogen detected in $77.6 \%$ of mobile phones. The healthcare workers' mobile phones can provide a reservoir of bacteria known to cause nosocomial infections and due to optimal preventing transmission of infection to patients, accurate determination of the different types of isolates is necessary. According to the recent recommendations of the United Kingdom National Health Service, regular cleaning of phones and hand hygiene have been introduced as main factors for prevention of spreading mobiles-related pathogens in hospital environments (10). According to the observation by Morioka et al. (11) while all the nurses were aware of hand washing with water or alcohol after regular work, 33.6\% of the nurses were not conscious of hand washing with water or alcohol after using a mobile phone. Therefore, because hand washing with water or alcohol prevents the contamination of the mobile phones, nurses should take standard precautions after using mobile phones. Our obtained bacterial contamination rate of staff's mobiles, as a main source of nosocomial infections, seems to be higher than that previously reported from other countries. In a similar study by Saxena et al.
(12) $42 \%$ of mobile phones carried by health care workers and $18 \%$ carried by the general public were found to carry one or more organisms. In addition, in another study by Singh et al. only the results of culture was positive for pathogenic bacteria in $34 \%$ of studied mobiles (13). In Sadat-Ali et al. study, $43.6 \%$ of health care providers carried infective organisms on their cell phones (14). Akinyemi et al. (15) showed that the rate of contaminations was $30.6 \%$ and $15.3 \%$ among lecturers/students and also health workers, respectively (11). In Ulger observation, $94.5 \%$ of phones demonstrated evidence of bacterial contamination with different types of bacteria (16). Similar observations were reported in other studies (17-21). High rate of contamination reported in our study is an important alarm and warning for our healthcare managers to fast track appropriate protocols of prevention and universal education to patients and staffs. In spite of different rate of contamination observed in our study and other similar studies, similarity in the types of isolated pathogens was observable between our findings and others. According to our results, the most common isolates were consecutively coagulase-negative staphylococci, S. aureus, and Pseudomonas species. In Morioka study, S. aureus was detected on $68.6 \%$ of mobiles (11). Akinyemi et al. showed that coagulase-negative staphylococci were the most prevalent bacterial agents from mobile phones, followed by S. aureus. Staphylococcus aureus was also the most common isolate in Datta et al. study (22).

In this context, there are two important points in our study. An important part of the isolated pathogens in our samples was detecting Pseudomonas species that was rarely reported in other studies; moreover, high resistance to ampicillin and ceftazidime was detected in our study cases. These two features distinguish our study from other studies, which might be another warning for our managers in health systems. In conclusion, mobiles contamination with different pathogens is extremely common among our healthcare staffs compared with other societies, and resistant of these isolates to various antibiotics is also detectable. Thus, quick assessment of this issue to prevent the spread of this infection is critical for the authorities in our health care systems.

\section{Acknowledgements}

We thank the Hamadan University of Medical Sciences authorities who offered critical administrative support and managerial services in performing the study and all researchers for their help and support.

\section{Funding/Support}

This study was supported by a grant from Hamadan University of Medical Sciences, Hamadan, Iran.

\section{References}

1. Karabay O, Koçoglu E, Tahtaci M. The role of mobile phones in the spread of bacteria associated with nosocomial infections.J Infect 
Dev Ctries. 2007;11(1):72-3.

2. Goldblatt JG, Krief I, Klonsky T, Haller D, Milloul V, Sixsmith DM, et al. Use of cellular telephones and transmission of pathogens by medical staff in New York and Israel. Infect Control Hosp Epidemiol. 2007;28(4):500-3.

3. Butcher $\mathrm{W}$, Ulaeto D. Contact inactivation of orthopoxviruses by household disinfectants. J Appl Microbiol. 2005;99(2):279-84.

4. Hota B. Contamination, disinfection, and cross-colonization: are hospital surfaces reservoirs for nosocomial infection? Clin Infect Dis. 2004;39(8):1182-9.

5. Gashaw M, Abtew D, Addis Z. Prevalence and Antimicrobial Susceptibility Pattern of Bacteria Isolated from Mobile Phones of Health Care Professionals Working in Gondar Town Health Centers. ISRN Public Health. 2014;2014(1).

6. Sowah LN. The future of the Mobile Internet: How do we tap into its fullest benefits. Technol Blogs. 2008;4(2):1-2

7. Brady RR, Wasson A, Stirling I, McAllister C, Damani NN. Is your phone bugged? The incidence of bacteria known to cause nosocomial infection on healthcare workers' mobile phones. J Hosp Infect. 2006;62(1):123-5.

8. Economist Intelligence Unit. Telecoms And Technology Forecast for Iran. 2008. Available from: http://www.eiu.com/home.aspx.

9. Wilker MA, Cockerill FR, Craig WA, editors. Performance standards for anti-microbial susceptibility testing: clinical and laboratory standards institute M 100-SI5.; 2005; Wayne, PA. National Committee for Clinical Laboratory Standards;

10. Brady RR, Hunt AC, Visvanathan A, Rodrigues MA, Graham C Rae C, et al. Mobile phone technology and hospitalized patients: a cross-sectional surveillance study of bacterial colonization, and patient opinions and behaviours. Clin Microbiol Infect. 2011;17(6):830-5.

11. Morioka I, Tabuchi Y, Takahashi Y, Oda Y, Nakai M, Yanase A, et al. [Bacterial contamination of mobile phones shared in hospital wards and the consciousness and behavior of nurses about bio- logical cleanliness]. Nihon Eiseigaku Zasshi. 2011;66(1):115-21.

12. Saxena S, Singh T, Agarwal H, Mehta G, Dutta R. Bacterial colonization of rings and cell phones carried by health-care providers: are these mobile bacterial zoos in the hospital? Trop Doct. 2011;41(2):116-8.

13. Singh S, Acharya S, Bhat M, Rao SK, Pentapati KC. Mobile phone hygiene: potential risks posed by use in the clinics of an Indian dental school. J Dent Educ. 2010;74(10):1153-8.

14. Sadat-Ali M, Al-Omran AK, Azam Q, Bukari H, Al-Zahrani AJ,Al-Turki RA, et al. Bacterial flora on cell phones of health care providers in a teaching institution. Am J Infect Control. 2010;38(5):404-5.

15. Akinyemi KO, Atapu AD, Adetona OO, Coker AO. The potentia role of mobile phones in the spread of bacterial infections. J Infect Dev Ctries. 2009;3(8):628-32.

16. Ulger F, Esen S, Dilek A, Yanik K, Gunaydin M, Leblebicioglu H. Are we aware how contaminated our mobile phones with nosocomial pathogens? Ann Clin Microbiol Antimicrob. 2009;8:7.

17. Jayalakshmi J, Appalaraju B, Usha S. Cellphones as reservoirs of nosocomial pathogens. J Assoc Physicians India. 2008;56:388-9.

18. Borer A, Gilad J, Smolyakov R, Eskira S, Peled N, Porat N, et al. Cell phones and Acinetobacter transmission. Emerg Infect Dis. 2005;11(7):1160-1.

19. Brady RR, Fraser SF, Dunlop MG, Paterson-Brown S, Gibb AP. Bacterial contamination of mobile communication devices in the operative environment. J Hosp Infect. 2007;66(4):397-8.

20. Mohammadi Sichani M, Karbasizadeh V. Bacterial contamination of healthcare workers' mobile phones and efficacy of surface decolonization techniques. Afr J Microbiol Res. 2011;5(3):5415-8.

21. Tagoe DN, Gyande VK, Ansah EO. Bacterial contamination of mobile phones: When your mobile phone could transmit more than just a call. Webmed Cent Microbiol .2011;2(10):1-12.

22. Datta P, Rani H, Chander J, Gupta V. Bacterial contamination of mobile phones of health care workers. Indian J Med Microbiol. 2009;27(3):279-81. 